\title{
THE SPENCERIAN AND COMTIAN NEXUS IN GOMPERS' LABOR PHILOSOPHY: THE IMPACT OF NON-MARXIAN EVOLUTIONARY THOUGHT
}

\author{
BY GEORGE B. COTKIN
}

Morris Hillquit remembered Samuel Gompers as bountifully graced with moral rather than intellectual power. What Gompers lacked in native ability, Hillquit maintained, he failed to make up in book learning. Compared to the urbane Sidney Hillman who read "Darwin, Marx, Mill, Spencer, and T. H. Morgan," Gompers was, according to historian Moses Rischin, a bon vivant who tried to be learned but never succeeded. ${ }^{1}$

As president of the American Federation of Labor almost continuously from 1886 until 1924 , Gompers was the bureaucrat qua intellectual. His actions and abilities largely shaped the American labor movement. Although Gompers cannot be identified as an intellectual who created a body of theoretical or original writings, he must be studied in an intellectual context. ${ }^{2}$ In this manner, his actions can be understood and the origins of "business unionism" or "pure and simple" trade unionism discerned.

Historians have undertaken this task, but their answers are contradictory. John R. Commons, Stuart B. Kaufman, and William Dick all stress the influence of Marxism upon Gompers' early intellectual development. For instance, Dick finds that "in the nineties, most of Gompers' ideas and his general outlook re-

\footnotetext{
${ }^{1}$ Morris Hillquit, Loose Leaves From a Busy Life (NY, 1934), 94; Moses Rischin, "From Gompers to Hillman: Labor Goes Middle Class," Antioch Review, 13 (June, 1953), 196.

${ }^{2}$ The Italian Marxist philosopher Antonio Gramsci would have characterized Gompers as an intellectual because he performed a specific social function based upon intellectual activity. See Selections From the Prison Notebooks of Antonio Gramsci, ed. and trans. by Quentin Hoare and Geoffrey Nowell Smith (New York, 1971), 9. Also, Jerome Karabel, "Revolutionary Contradictions: Antonio Gramsci and the Problem of Intellectuals," Politics \& Society, 6 (1976), 123-72.
} 
flected "sound Marxist principles." These historians argue also that Gompers developed his concept of pure and simple trade unionism under the influence of trade union Marxists like Ferdinand Laurrell, J. P. McDonnell, and Adolph Strasser. Crucial in the growth of Gompers' trade union principles, according to Commons, was the Swedish immigrant cigar maker, Ferdinand Laurrell, who told Gompers, "Study your union card, Sam, and if the idea does not square with it, it ain't true." ${ }^{3}$

Gerald N. Grob and Bernard Mandel offer a different interpretation. They deny any nexus between ideology and action; Gompers always acted pragmatically. Thus, the AFL had "a philosophy of action and a state of mind," that, Grob stated, "... paid little attention to theories of reform and social transformation." Mandel agreed, stating that "Gompers didn't trust theories even as a guide to action. ..." In their view, Gompers' trade unionism was marked by practical rather than theoretical beliefs; it tailored action to fit the environment. ${ }^{4}$

These interpretations leave much to be desired. At least the Marxian-milieu-view that accepts the relationship between ideas and environment correctly recognizes the necessity of placing Gompers in an intellectual context. But can Gompers' actions be understood as solely influenced, in terms of their intellectual genesis, by Marxian thought alone? Such a formulation accepts a Marxian world view as dominant among trade unionists throughout the 1880s. Yet important trade unionists like Frank K. Foster and Hugh McGregor had abandoned Marxism by this period: Foster for a Spencerian world view, McGregor for the "Positive Philosophy" of Auguste Comte. Both had rejected Marx and

${ }^{3}$ William M. Dick, Labor and Socialism in America (Port Washington, NY, 1972), 47; John R. Commons, "Karl Marx and Samuel Gompers," Political Science Quarterly 41 (June, 1926), 282; Stuart B. Kaufman, Samuel Gompers and the Origins of the American Federation of Labor, 1848-1896 (Westport, CT, 1973); $H$. M. Gitelman also finds Marxian influence behind the development of the AFL's union principles in "Adolph Strasser and the Origins of Pure and Simple Unionism," Labor History, 6 (Winter, 1965), 71-83. Philip Taft also acknowledges Gompers' close contact with trade union Marxists, The A.F. of L. in the Time of Gompers (NY, 1957), 38-39. Laurrell is quoted in Foster Rhea Dulles, Labor in America (NY, 1960), 154.

${ }^{4}$ Gerald N. Grob, Workers and Utopia (Chicago, 1961), 141-142; Bernard Mandel, Samuel Gompers, A Biography (Yellow Springs, OH, 1963), 52. Also see Mande1, "Gompers and Business Unionism, 1873-1890," Business History Review 23 (Sept., 1954), 264-65. Clifton K. Yearly calls Gompers "An opportunist by nature, he was controlled by circumstances within his environment, so much so that hardly ever in his career was he able to impose himself upon them." South Atlantic Quarterly, 56 (Summer, 1957), 334. 
nevertheless become pure and simple trade unionists.

Considered a man of great intellect by Gompers, ${ }^{5}$ Foster was a prominent trade union journalist, author of an autobiographical novel and a book of poems, Secretary of the Federation of Organized Trades and Labor Unions (which evolved into the AFL), and a leading theorist of pure and simple trade unionism. ${ }^{6}$ McGregor, a jeweler by trade, after involvement with the First International (Section 12) and the Social Democratic Party of North America in the early 1870 s, later served as Gompers' clerk and confidant in the 1880 s. In the 1890 s McGregor was General Secretary of the International Amalgamated Society of Seamen and Firemen and a frequent contributor of articles on history and trade union theory to the Carpenter and the American Federationist. $^{7}$

The thesis that Marxians like Laurrell and Adolph Strasser redirected their Marxism, complete with an anti-political stance, into pure and simple trade unionism does not tell the entire story. This is not to deny Marxian influences upon Gompers; his acceptance of a theory of class society and the need for a purely working-class organization is Marxian inspired. But the ideas of trade union Marxians must be located in the context of the overall American intellectual environment-one need not always remain a Marxist or simply go from pure to revisionist Marxism. In response to intellectual, socio-cultural, and economic pressures, one could replace Marxism with an antagonistic ideology. Frank Foster and Hugh McGregor, for instance, moved away from their Marxism of the 1870s due to the influence of non-Marxian evolutionary thinkers. Historians must be aware of conflicting or similar mind-sets when they approach trade union rhetoric. A statement that seems to indicate inevitable progress and class conflict may be attributed to a Marxian world view when, in fact, it was more clearly influenced by non-Marxian evolutionary doctrines. ${ }^{8}$

\footnotetext{
${ }^{5}$ Samuel Gompers to Mrs. Frank K. Foster, Dec. 4, 1904, Samuel Gompers Letterbooks (SGLB), AFL-CIO Collection, v. 151.

- Biographical information on Foster can be found in Arthur Mann, Yankee Reformers in the Urban Age (NY, 1966), 188-200; George E. McNeill, ed., The Labor Movement (Boston, 1887), 607-08.

${ }^{\top}$ Gompers talks about McGregor in Seventy Years of Life and Labour (London, 1925), I, 272-75, 329-30.

${ }^{8}$ Dick often makes this error, $23-24,35,113$. Historians have hinted at the nonMarxian evolutionary texture of Gompers' thought, see Fred Greenbaum, "The Social Ideas of Samuel Gompers," Labor History 1 (Winter, 1966), 37, and Mi-
} 
The intellectual influences exerted by McGregor and Foster upon Samuel Gompers have been totally ignored by historians. Gompers and others have left us some indications of their importance. Socialist Moses Oppenheimer was certain that Gompers' trade unionism became understandable only when his allegiance to Hugh McGregor became known. As Oppenheimer saw it, "In order to understand G. [Gompers], it is necessary to know the enormous influence exerted upon him . . . by Hugh McGregor ... which formed the theory upon which he has acted.... This theory $\mathrm{McG}$ instilled into $\mathrm{G}$ by dint of patient iteration; $\mathrm{G}$ was a slow pupil, but a retentive one; his small mind perceiving this theory, held it as a dogma and has had no room for any other." Gompers himself acknowledged that he often "attended, enjoyed and participated" in discussions with McGregor and other trade union members of the Positivist church. In his autobiography, Gompers stated that his association with this group helped him "to discern the sound from the unsound, theories from facts and to absorb the best and reject the spurious." If this was the accomplishment of the Positivists, then their role in shaping Gompers' trade union philosophy cannot be neglected. Another account by lower East Side labor activist Gregory Weinstein rememhered Gompers' reliance upon Positivist trade unionists like Edward King. In the formation of the first New York Central Labor Union, Weinstein recalled that, "King was the brains of the group while Gompers supplied the dramatic and dynamic forces." :

Gompers was also in close intellectual contact with Frank Foster, whose Spencerianism had led him from Marxism to a near anarchism according to Benjamin Tucker, the anarchist journalist. Other unionists, such as Henry Weismann, August McGraith, and Joseph Labadie, shared Foster's idolatry of Spencer and flirted with anarchism. These men allied with Gompers in the early 1890 s to fight the socialists in the organization, most notably at the 1894 AFL convention. It was as a balm for Gompers' ego, after his defeat as president of the organization in 1894, that

chael Rogin, "Voluntarism: The Political Functions of an Antipolitical Doctrine," Industrial and Labor Relations Reviews, 15 (July, 1962), 521-35, esp. 521-23.

${ }^{\circ}$ Algernon Lee Papers, "Diary," Tamiment Library, 121; Gompers, Seventy Years, I, 104-05. Historians have ignored totally the impact of Positivism upon American trade unionism. Positivism's influence upon the development of British unionism is discussed by Royden Harrison, Before the Socialists (London, 1965), 251-342. and Gregory Weinstein, The Ardent Eighties and After (NY, 1947), 86. 
Foster and a group of Boston trade unionists presented Gompers with the works of Herbert Spencer. While Gompers may not have read the volumes during his year's hiatus from the AFL presidency, Gompers did occasionally quote Spencer and announced in his autobiography that he had "read with great care and interest the works of Herbert Spencer." If Gompers did not regularly turn to Spencer for clarification of trade union policy, he did often turn to Foster for advice. Gompers was a regular reader of Foster's Labor Leader journal, where Spencer's doctrines were frequently discussed, and often he wrote to Foster for guidance on trade union theory. ${ }^{10}$

Foster and McGregor, firm believers in their intellectual mentors, Spencer and Comte, constantly offered theoretical guidance to Samuel Gompers. While it is impossible to know exactly how much of their reasoning Gompers accepted, one can look at their formulations to see how closely they paralleled official AFL policy as expressed by Gompers.

Certainly Spencer and Comte had differences in their respective philosophies. Most importantly, Spencer apotheosized the individual, while Comte spoke of social duties. ${ }^{11}$ Yet both thinkers were proponents of the idea of progress and took a dim view of the efficacy of political action. Foster and McGregor accepted these beliefs and in turn added a few of their own: progress was expressed through the trade union, and individualism reached its fullest beneficence when men joined together in a trade union. These precepts, as argued by Foster and McGregor, were accepted by Gompers.

${ }^{10}$ Liberty, 8 (Sept. 12, 1891 ) , 3; J. F. Finn stresses the role of philosophical anarchism in shaping the AFL's ideology in "A.F. of L. Leaders and the Question of Politics in the early 1890s," Journal of American Studies, 7 (1973), 243-65. See Gompers, Seventy Years, I, 361-62 and also the following letters from Gompers to Foster, all in SGLB: July 26, 1897, v. 20; Oct. 1, 1903, v. 78; July 6, 1905, v. 102; Aug. 8, 1906, v. 114.

${ }^{11}$ Spencer's laissez-fairism is adequately recounted in his essay "Over-Legislation," in Essays, Moral, Political and Aesthetic (NY, 1881), 48-106 and The Man Versus the State, ed. Truxton Beale (NY, 1916). Comte discusses social solidarity in his Positive Philosophy, trans. Harriet Martineau II (3rd ed. London, 1893), 66ff, and in $A$ General View of Positivism, trans. J. H. Bridges (London, 1865), 136ff. Many contemporary observers bunched Comte and Spencer together. See, for instance, James McCosh, Christianity and Positivism (NY, 1871), 167. More recent commentators also find similarities, John C. Greene, "Biology and Social Theory in the Nineteenth Century: Auguste Comte and Herbert Spencer," in Marshall Clagett, ed. Critical Problems in the History of Science (Madison, 1959), 419-46; Ronald N. Stromberg, European Intellectual History Since 1789 (NY, 1968), 107; Floyd W. Matson, The Broken Image: Man, Science and Society (NY, 1966), 23. 
To view the similarity of ideas expressed by McGregor, Foster, and Gompers, it will be necessary to juxtapose their thoughts on the role of the state and legislation and on the possibility of progress through the trade union. Gompers was certainly no less influenced by Foster and McGregor than by Marxians like Laurrell and Strasser. If this is the case, then historians must take into account the non-Marxian intellectual origins of Gompers' pure and simple trade unionism.

Frank K. Foster presented a theory of trade unionism that stressed the individual and rejected the state. He demanded equilibrium in all theories and searched for it in his own. Equilibrium meant that one must avoid dogmatism and extremes. In his openness to possible solutions to the labor problem, Foster's thought evidenced some similarity to the pragmatism of William James and the pragmatic unionism of the AFL. Such pragmatism did not necessarily deny a theoretical bias; for Foster this theory was supplied by popular evolutionary thought. To a man who found Darwinism "all pervasive in its influence" and considered Herbert Spencer the major philosopher of his age, it is not surprising to find Foster arguing against coercion in favor of voluntarism, praising the role of the individual in initiating change or arguing against the state. ${ }^{12}$

As Foster became more interested in evolutionary thought in the early $1890 \mathrm{~s}$, his views toward state interference and legislation concerned with trade union matters changed. In 1886 Foster had believed in the efficacy of state legislation to gain the eight hour day. By 1894 Foster's anti-statism coalesced with the views of voluntaristic trade unionism. Indicative of this change was Foster's position on a bill introduced by one Representative George of Haverhill in the Massachusetts legislature. George's bill would have limited to 54 the number of hours workers could legally be employed in the state. Foster rejected this idea. The issue was not how few or how many hours a worker might work, declared Foster, but one of state compulsion. Foster denounced the legislature for believing it had any power to dictate the number of hours labor could negotiate to work. He further called the soonto-be forgotten bill "a direct hindrance to the legitimate short hour movement" because it "teaches men to look to that shadowy

${ }^{12}$ Labor Leader, 5 (Jan. 5, 1889), 2. 
entity, the state, for things they can do better themselves." Foster's Spencerian beliefs did not lead him to a complete negation of government. Child labor laws and compulsory child education laws were accepted by Foster who viewed minors, and to a lesser extent women, as unable to protect themselves. ${ }^{13}$

Gompers also preferred union power to state intervention and legislation. In common with Foster, Gompers was not dogmatic; when the issue at stake was child labor laws, Gompers was favorable. Both Gompers and Foster opposed charity in the manner of Herbert Spencer. Foster rejected handouts unless the situation was dire, as in the depression year of 1893. Gompers denounced charity as "injurious," and lectured: "Men who accept charity unless their conditions very materially change are likely to become accustomed to depend upon that charity, and make no good effort to work out of the rut." The "charitable" ideas of the state fixing "fair" wage rates for workers in private employment was anathema to Gompers. He refused to place any faith in the state: "If government has the right to establish the minimum, it may also establish a maximum." Gompers' theory and practical view of the state in this instance reinforced one another. For example, Gompers lectured Morris Hillquit during their debate before the United States Commission on Industrial Relations:

The attempts of Government to establish wages at which workmen may work is in the experience of history, the beginning of an era, and a long era, of industrial slavery. ${ }^{14}$

Even more injurious and theoretically incorrect than state charity or wage regulations were laws mandating arbitration of labor disputes. These laws became a panacea in the early twentieth century and were viewed as the ultimate solution to labor

${ }^{13}$ Haverhill Laborer, 1 (Feb. 28, 1885), 2; The Laborer, 2 (Jan. 23, 1886), 1; Labor Leader, 15 (March 3, 1894), I; FOTLU Convention Proceedings (1883), 21; Labor Leader, 3 (Jan. 18, 1888), 2.

${ }^{14}$ Roger W. Walker, "The A.F.L. and Child-Labor Legislation," Labor History, 2 (Summer, 1970), 324; Herbert Spencer, "Over-Legislation," 100; Mann, 194; Gompers, "On the Attitude of Organized Labor Toward Organized Charity," March 20, 1899 in A.F. of L. Papers, Series 11, Box 48, Wisconsin State Historical Society; Gompers, "Compulsory Arbitration in the Railroad Engineers' Award," American Federationist, 20 (Jan., 1913), 17. Gary Fink suggests that Gompers' antipolitical views were not shared by local trade unionists, Labor's Search for Political Order (Columbia, MO., 1973), 6, 9, 164. While this may be true, Gompers' belief in voluntarism remains unchallenged and it cannot be denied that he tried to impose his views upon local trade unionists. See Rogin, 521-23 and The Double Edge of Labor Sword (NY,1971), 98. 
strife. Compulsory arbitration laws, like the Lemieux Act of Canada or the Lusk Act of New Zealand, were regularly discussed in the American Federationist and always negatively by the journal's editor Samuel Gompers. He found the Lemieux Act absolutely dangerous to the union movement; it would, he argued, force weak unions into poor agreements and weaken strong unions. Gompers preferred to continue labor relations upon the old basis. With this in mind he announced in bold type, "ONLY THE STRONG CAN WIN PEACE AND MAINTAIN PEACE WITH JUSTICE." Faith must not be placed in a strong government but in the voluntary association of wage workers. Foster agreed with Gompers on the crucial role of the trade union and buttressed his case with Spencer's definition of liberty as "the freedom to exercise one's faculties." Foster applied this definition to the union movement and argued for voluntarism and antistatism as the workers' only road to emancipation..$^{15}$

Labor's argument against state interference and compulsory arbitration proceeded along Spencerian lines. State interference in the natural workings of the political economy was injurious to progress. Foster accepted Spencer's "Law of Progress" based upon evolutionary science. In addition, Foster tied such progress to the success of the trade union because the union had "organically evolved' out of the necessities of the people who are forced to sell labor for day's wages." Gompers found the New Zealand compulsory arbitration law "an effort to pursue an unnatural course to meet a natural situation and condition." Struggle, in Gompers' and Foster's mind, was natural and not to be condemned. Gompers passed a predictable judgment upon the commission of 1912 that was to adjust the differences in wage proposals between the eastern railroads and the locomotive engineers:

Everybody recognizes that peace is a desirable goal, that war is destructive and an interruption of progress. But in our zeal to reach this ideal let us beware lest we sacrifice justice and freedom to peace; lest we forget the ancient chains that held men in bondage. Peace under this fair sounding name is not of a nature to promote human welfare. ${ }^{16}$

\footnotetext{
${ }^{15}$ Gompers, "Tying Workers to their Tasks through Compulsory Government 'Investigation'," American Federationist 20 (Feb., 1913), 124; Foster, "Reply to President Eliot," Eliot Papers, Harvard University Archives, 7; Labor Leader, 2 (Feb. 18, 1888), 2; 7 (May 3, 1890), 2; 18 (Nov. 9, 1895), 1.

${ }^{18}$ Foster, The Evolution of a Trade Unionist (Boston, 1901), 173; Labor Leader, 7
} 
When Gompers turned to the government before World War I, it was only under duress. His well-publicized 1906 "Labor's Bill of Grievances," which called for an eight hour day for all government employees, regulation of convict and immigrant labor, an end to the use of injunctions to break strikes and a host of other proposals, was more rhetoric than substance. Labor's grievances were real but Gompers' desire to use the good offices of the government was illusory. His 1906 political campaign was clearly designed to placate the socialist element in the union movement, who demanded government action to cure labor's ills. Gompers stated as much in a 1906 letter to Frank Foster. He admitted that he had little hope for his political campaign, but Gompers preferred to see it doomed to failure if success meant the neglect of union affairs. ${ }^{17}$

Moses Oppenheimer, who knew Gompers from the early days of the New York labor movement, offered this very thesis to socialist educator Algernon Lee in 1906. As Oppenheimer interpreted the situation, rank and file pressure had forced Gompers to sanction AFL involvement in a political and legislative campaign. Gompers hated this move because it clashed with his Positivist trade union education at the hands of Hugh McGregor. According to Oppenheimer, McGregor had taught Gompers the following lesson:

History records a succession of class dominations. Each ruling class in turn has been subdued ... by the effort of a class rising from below. But the rising class cannot win by using the weapons or methods of the class against which it is revolting. Thus, the trading classes did not conquer the warrior class by force of arms, it developed its own appropriate method-that of parliamentary action. The trading class now rules, having the warriors and others as its servants or agents. It is now the turn of the working class to rise to power, overcome the traders and convert them into servants of the new order. But in so doing the working class must not depend upon the peculiar method of the traders; on the field of parliamentary politics the trading class is strong enough to defend itself; the rising class must develop its own method, fitted to its class nature, and can expect only failure from participation in politics.

(Jan. 25, 1890), 1; Samuel Gompers to D. H. Sullivan, Dec. 11, 1892, v. 182 SGLB; Gompers, "Compulsory Arbitration in the R.R. Engineers' Award," American Federationist, 17.

${ }^{27}$ Fink, 14-15; Taft, 294-95; Samuel Gompers to Frank K. Foster, Aug. 8, 1906, v. 114, SGLB. 
Gompers probably received the same lecture from other trade union members of New York City's thriving Positivist community. As his autobiography suggests, Gompers always respected their views and considered their teachings invaluable to his education. $^{18}$

McGregor was a spokesman for progress through the organization of the working class into trade unions. As a painstaking if unimaginative historian, McGregor traced the presence of trade unions throughout history. A Comtian, McGregor accepted an evolutionary view of history: he regarded all spheres of human activity as having passed from the theological through the military to the industrial period. The labor union as an "organic body" had been present in every stage of development; it would triumph in the newest period of organization, the industrial. Success, however, depended upon the labor movement's adhering to McGregor's two major concepts of historical progress: unity and slow change. Samuel Gompers built the AFL upon these same basic premises. ${ }^{19}$

Labor union unity was difficult due to jurisdictional disputes and the Socialist Labor Party's and the Industrial Workers of the World's dual union policies. In the everyday world of trade unionism, jurisdictional disputes were to be regretted but were generally seen as unavoidable. The role of socialists in suggesting and at times implementing a different course for the labor movement was not seen as unavoidable. Socialist tampering with the union movement turned Gompers, McGregor, and Foster into vehement opponents of any type of socialism. In addition, Gompers, McGregor, and Foster each had their own personal socialist bogeyman-Daniel DeLeon, Frederick Sorge and Henry Abrahams respectively. Personal animosity can play a large role in the affairs of men, especially when one of the antagonists could harbor a grudge like Gompers. In Gompers' antipathy towards socialists we can discern two interconnected causes: personal ani-

\footnotetext{
${ }^{18}$ Algernon Lee Papers, "Diary," Tamiment Library, 121; Gompers, Seventy Years, I, 104-05. For additional material on the thriving New York trade union Positivist community see Le Revue Occidentale, 18 (Premiere Semestre, 1887), 278-82; Weinstein, 217; Abraham Cahan, The Education of Abraham Cahan (Phila, 1967), 248.

${ }^{19}$ For McGregor's view of history and progress see his historical essay, "A Rough Sketch of a Rough Struggle," Carpenter, 13 (Aug., 1893), 9, through 15 (Jan., 1896), 10; also McGregor "The Incorporation of the Working Class," Forum, 24 (Jan., 1898), 579-90.
} 
mosity and a pragmatic assessment of the dangers of a divided labor movement. What is missing is the purely theoretical or intellectual differentiations that turned Gompers, McGregor, and Foster against the socialists. This intellectual rejection can be most clearly shown through an examination of these three pure and simple trade unionist's conception of historical progress and the trade union's role in such change.

McGregor closely tied the saga of civilization to labor. In a dialectic of development within historical periods, McGregor demonstrated how labor had risen to the highest point possible in the theological and military periods. History, as interpreted by McGregor, proved that labor would triumph in the industrial period of evolution. Shed of Comtian jargon, McGregor's historical survey revealed two concepts crucial to the ideology of the AFL. First, the labor organization is natural and progressive. Second, and more important, by connecting universal progress to the evolution of unionism, McGregor presented an historical rationalization and imperative to the craft union movement. In essence, McGregor certified that American organized labor was pursuing the historically, and concomitantly socially, correct line of development. Oppenheimer, in many ways, correctly placed Gompers' sense of righteousness-he actually called Gompers "narrow-minded," "egotistic" and "stubborn"- that allowed him to condemn industrial unionism or politics, not solely in a pragmatic or personal sense, but in the context of a particular historical interpretation. Gompers' certitude in labor's evolutionary role and his correct interpretation of it led him to write:

So convinced am I however, that the trade union movement is the natural organization of labor, that they will continue to grow and prosper and work out the emancipation of labor despite the antagonism of pretended friends and open enemies, that I can look with equanimity upon the abuse they can heap upon me.

Gompers believed that his steadfastness not only assured labor's progress but also insured the progress of the entire nation. This was a sobering responsibility; but in the Comtian terms of reciprocity and social feelings, of which McGregor regularly wrote, Gompers hoped that as unions grew they would cease being "indiscreet" and learn their rights and duties in a social context."

${ }^{30}$ Carpenter, 12 (Nov. 2, 1892), 4; Samuel Gompers to Jas. McGill, April 13, 1892, v. 7, SGLB; Samuel Gompers to Earl Kelly, June 2, 1900, v. 34, SGLB. 
The interrelatedness of social and labor progress was also expressed in a Spencerian context by Frank Foster. For Foster, as well as for McGregor, the labor organization was an organic and a scientific form of organization. It was scientific because Foster saw in the union an organization that accepted the competition that marked society while offering a way out of it. In Foster's view the union successfully merged individuals into a social unit. Thus did workers gain a social spirit predicated upon voluntary solidarity. In this manner they gained tangible wage benefits and retained their individuality. Foster considered his trade union formula reasonable and sure to lead to societal progress. The union was "in common with all physical and mental phenomena ... subject to the law of evolution." Foster believed that voluntaristic trade unionism, so long as it guarded the rights of the individual, was sure to succeed in a world marked by struggle. ${ }^{21}$

All socialists, even Lassalleans, regarded the trade union as having an important role to play in societal evolution. But Gompers, McGregor, and Foster differed from socialist in that they rejected revolution and sudden change as bonafide methods to elevate the working class.

McGregor saved his greatest vehemence for what he considered the undeniable belief in cataclysmic revolution throughout Marx's writings. Marx's "ingrained materialism" disgusted McGregor. Such materialism, according to McGregor, led Marx away from the importance of social structures to a simplistic economic determinism. McGregor, in common with his master Auguste Comte, saw change as gentle and evolutionary and based more upon changes in ideas than upon changes in the economic base of society. Progress was assured when men proceeded through reason to change society and when they learned and built upon the past. McGregor explained that when man expected sudden changes he flew in the face of scientific evolution. Such changes only served to plunge humankind backwards. ${ }^{22}$

Foster also condemned the socialists for their inability to understand scientific evolution. A true child of his age, Foster called

\footnotetext{
${ }^{21}$ Labor Leader, 1 (Sept. 18, 1887), 2; Foster, The Evolution, 170. Foster, "Shoemakers in the Movement," in McNeill, ed., The Labor Movement, 201.

$=$ McGregor was not a sanguine prophet of progress. While he rejected, with some reservations, Vico's inevitable cycles of history thesis, McGregor did not argue with Darwin's and Spencer's occasional undercurrents of retrogression in their writings. Carpenter, 17 (July, 1897), 8; 13 (Aug., 1893), 9; 16 (July, 1896), 3.
} 
for moderation and equilibrium because too much state interference or change upset society and impeded progress. A close balance exists between physical and social laws, proclaimed Foster; when this balance is upset by a revolution, cataclysm results. ${ }^{23}$ From this view of evolution Foster easily regarded the AFL's policy of moderation and immediate gains as the evolutionarily prescribed course.

This belief in slow and evolutionary progress as the proper course is integral to Gompers' thought as well. Gompers admitted that the trade union movement might be slow in improving the workers' plight; but he echoed McGregor's fears of retrogression if too much were attempted, when he wrote that pure and simple trade unionism may

be slow, too slow even to satisfy the impatience of men burning with indignation against the wrongs that exist, yet in my judgment it is the very apparent slowness with which they move which in the end is the best progress that can be made to secure our movement against reaction and retrogression. ... In physical life as well as in our movement, you will find the man who continually with all directed purposes is far more capable of achieving permanent results than the one who spasmodically makes a spurt. ${ }^{24}$

The belief in slow evolution and moderation could also allow Gompers to reassure employers of the AFL's intentions. In a speech delivered before the National Civic Federation Gompers told his audience that he believed in evolutionary progress. "Improvements are going to occur," said Gompers; the question is one of method: revolution as in Russia or "the plain, modest, American evolutionary method of attaining betterment through the trade union movement." ${ }^{25}$ Gompers' appeal for business understanding was indicative of the extent to which he accepted the ideas of popular evolutionary thought, especially its faith in progress and rejection of revolution.

Can one claim that Gompers' contact with McGregor and Foster and non-Marxian evolutionism convinced him of the proper trade union course to follow? Non-Marxian trade union

${ }^{23}$ Foster, The Evolution, 112-15. The motto of Foster's journal The Laborer was "Evolution Not Revolution."

${ }^{4}$ Samuel Gompers to A. S. Leith, Jan. 25, 1892, v. 6, SGLB. For a similar statement, "Whatever changes are to come will come as a development, not as a cataclysm," see Gompers, "Industrial Unionism," American Federationist, 19 (May, 1912), 374.

${ }^{25}$ American Federationist, 12 (June, 1905), 374. 
theory did not tell Gompers what to do in a practical and particular situation. He responded, however, not without a theoretical bias. Such a bias did keep him from doing certain things. For instance, he would not plunge the AFL into a political campaign or enter into a real industrial unionization program. His antipathies to these courses of action, in retrospect no less pragmatic than the options that he exercised, were influenced and supported by the Spencerian ideas of Frank K. Foster and the Comtian ideas of Hugh McGregor. These views, in turn, helped guide the AFL along its course of development until the First World War. 